\title{
Role of Mas Receptor Antagonist A799 in Renal Blood Flow Response to Ang 1-7 after Bradykinin Administration in Ovariectomized Estradiol-Treated Rats
}

\author{
Aghdas Dehghani, ${ }^{1,2}$ Shadan Saberi, ${ }^{1,2}$ and Mehdi Nematbakhsh ${ }^{1,2,3}$ \\ ${ }^{1}$ Water \& Electrolytes Research Center, Isfahan University of Medical Sciences, Isfahan 81745, Iran \\ ${ }^{2}$ Department of Physiology, Isfahan University of Medical Sciences, Isfahan 81745, Iran \\ ${ }^{3}$ Isfahan ${ }^{M N}$ Institute of Basic \& Applied Sciences Research, Isfahan 81546, Iran \\ Correspondence should be addressed to Mehdi Nematbakhsh; nematbakhsh@med.mui.ac.ir
}

Received 31 May 2015; Revised 11 August 2015; Accepted 12 August 2015

Academic Editor: Thérèse Di Paolo-Chênevert

Copyright (C) 2015 Aghdas Dehghani et al. This is an open access article distributed under the Creative Commons Attribution License, which permits unrestricted use, distribution, and reproduction in any medium, provided the original work is properly cited.

\begin{abstract}
Background. The accompanied role of Mas receptor (MasR), bradykinin (BK), and female sex hormone on renal blood flow (RBF) response to angiotensin 1-7 is not well defined. We investigated the role of MasR antagonist (A779) and BK on RBF response to Ang 1-7 infusion in ovariectomized estradiol-treated rats. Methods. Ovariectomized Wistar rats received estradiol (OVE) or vehicle (OV) for two weeks. Catheterized animals were subjected to BK and A799 infusion and mean arterial pressure (MAP), RBF, and renal vascular resistance (RVR) responses to Ang 1-7 (0, 100, and $\left.300 \mathrm{ng} \mathrm{kg}^{-1} \mathrm{~min}^{-1}\right)$ were determined. Results. Percentage change of RBF (\%RBF) in response to Ang1-7 infusion increased in a dose-dependent manner. In the presence of BK, when MasR was not blocked, \%RBF response to Ang 1-7 in OVE group was greater than OV group significantly $(P<0.05)$. Infusion of $300 \mathrm{ng} \mathrm{kg}^{-1} \mathrm{~min}^{-1} \mathrm{Ang}$ $1-7$ increased RBF by $6.9 \pm 1.9 \%$ in OVE group versus $0.9 \pm 1.8 \%$ in OV group. However when MasR was blocked, \%RBF response to Ang 1-7 in OV group was greater than OVE group insignificantly. Conclusion. Coadministration of BK and A779 compared to BK alone increased RBF response to Ang 1-7 in vehicle treated rats. Such observation was not seen in estradiol treated rats.
\end{abstract}

\section{Introduction}

Women are shown to be protected against cardiovascular and renal diseases before menopause, suggesting that estrogen has beneficial roles in this respect [1-3]. Estrogen affects reninangiotensin system (RAS) by stimulating the depressor pathway of this system [4-6], while this sex hormone enhances the kallikrein-kinin system (KKS), leading to the renoprotective effect $[7,8]$.

The heptapeptide angiotensin 1-7 (Ang 1-7) is a biologically active peptide of RAS, especially in the kidney $[9,10]$ via G-protein coupled Mas receptor (MasR) [11]. Ang 17 induces vasodilator response to attenuate the actions of angiotensin II (Ang II) [12] and therefore plays pivotal role in cardiovascular and renal systems [13, 14]. Endogenous levels of Ang 1-7 are increased by angiotensin converting enzyme (ACE) or Ang II type 1 receptor (AT1R) inhibitors indicating that the protective effects of ACE or AT1R blockers are exerted by augmenting of this peptide [15, 16]. Ang 17 formation is different in the circulation and kidney [17, 18]. In circulation, neutral endopeptidase (NEP) is the main enzyme that produces Ang 1-7 [19], while the major enzyme that contributes to renal Ang 1-7 synthesis is ACE2 as ACE homologue $[17,18]$. In general, the ACE2/Ang 1-7/Mas axis has a key role in renal hemodynamics.

KKS is also involved in the control of renal hemodynamics and function [20]. This system forms active peptides called kinins that have two distinct receptors, namely, B1 and B2 receptors [21]. Bradykinin (BK) is a main component of the KKS generated from kininogens by the kallikreins [21] and is expressed within the kidney [22]. In the kidney, the local infusion of BK enhances sodium and water excretion [23], while it mediates some functions via $\mathrm{B} 2$ receptor, including vasodilatation, natriuresis, and dieresis $[23,24]$. It is well 
known that $\mathrm{ACE}$ participates in degradation of $\mathrm{BK}$, and $\mathrm{ACE}$ inhibitor elevates the BK level. Therefore, the positive effects of ACE inhibitor in the kidney can be exerted by enhancing and prolonging the effects of $\mathrm{BK}[25,26]$. Ang 1-7 increases BK-induced vasodilator effects by activation of mediated factors, nitric oxide (NO) and prostaglandin release [21, 27]. It is demonstrated that cooperation between Ang 1-7 and BK potentiates vasodilatory response, mediated by endotheliumdependent release of $\mathrm{NO}$ [27], and coadministration of Ang 1-7 and BK causes hypotension [28]. In addition, B2 receptor antagonist, HOE-140, abolishes the vasodepressor effects of Ang 1-7 [28]. On the other hand, inhibition of MasR by A779 leads to blockade of BK and potentiating activity of Ang 1-7, indicating that MasR is involved in mediating the vasodilation effect [29].

Renal diseases usually are influenced by RBF disturbance [30-32] hormone dependently [3], and MasR, BK, and NO are abundant in the kidney too [33-36]. On the other hand, female sex hormone, estrogen, plays an important role in regulation of RAS and KKS [5-7]. This complex data raises the question about the role of estrogen and BK in renal Ang 1-7-Mas axis function.

Therefore, it is hypothesized that BK and estradiol may influence RBF response to Ang 1-7 via MasR. To examine this hypothesis, MasR was inhibited by A779 and in the presence of BK, the response of RBF to Ang 1-7 was measured in ovariectomized rats treated with estradiol, and the results were compared with those obtained from the control group.

\section{Methods and Materials}

2.1. Animals. Female rats were housed in the animal room with controlled temperature of $23-25^{\circ} \mathrm{C}$ and $12 \mathrm{~h}$ light/dark cycle. The rats were kept in cages with free access to water and chow. All experimental procedures were in advance confirmed by Isfahan University of Medical Sciences Ethics Committee.

Female Wistar rats $(200 \pm 20 \mathrm{~g})$ were anesthetized $(0.06 \mathrm{~g} / \mathrm{kg}$ of ketamine $10 \%$ and xylazine $2 \%$ solution $)$ and ovariectomized as described before [37]. After one week of recovery, the animals were randomly assigned into two groups named OVE as the treated group and OV as the control group. The animals in OVE group received estradiol valerate $(500 \mathrm{~g} / \mathrm{kg} /$ twice weekly, im) dissolved in sesame oil, while OV group received vehicle (sesame oil) for estradiol for two weeks. The animals were then subjected to surgical procedure.

2.2. Surgical Procedure. The rats were anesthetized by urethane $\left(1.7 \mathrm{~g} / \mathrm{kg}^{-1}\right.$ i.p.; Merck, Germany). The trachea was cannulated for air ventilation and polyethylene catheters were inserted into the carotid and femoral arteries and jugular vein for direct mean arterial pressure (MAP) and renal perfusion pressure (RPP) measurements and drug administration, respectively. Arterial catheters were connected to a pressure transducer and bridge amplifier (Scientific Concepts, Melbourne, VIC, Australia) and attached to a data acquisition system. The bladder also was catheterized to collect urine output. Body temperature was monitored continuously through the experiment. An adjustable clamp was put around the aorta above the renal artery to maintain RPP at the control level during Ang 1-7 infusion. With midline incision, the kidney was exposed and placed in a kidney cup. A transittime ultrasound flow probe (Type 2BS; Transonic Systems, Ithaca, NY, USA) was placed around the renal artery to measure RBF. Then, 30-60 minutes after the equilibration period, basal MAP, RPP, and RBF were recorded and RVR was calculated as RPP/RBF.

2.3. Experimental Protocol. Both groups of OV and OVE underwent the experimental protocol according to the following procedure. After measurement of MAP, RPP, and RBF in the equilibration time, A779 or combination of BK and A779 was infused via the vein catheter. Therefore, in each group, we assigned two subgroups. Subgroup 1 and subgroup 2 from OV group received BK and BK + A779, respectively. Such treatments were applied in subgroups 1 and 2 from OVE group. A779 is a selective MasR antagonist and also has negligible affinity for Ang II receptors [38]. It was administrated at bolus doses of $50 \mu \mathrm{g} / \mathrm{kg}$ followed by continuous infusion at $50 \mu \mathrm{g} / \mathrm{kg} / \mathrm{h}$. BK as B2 agonist was infused at $150 \mu \mathrm{g} / \mathrm{kg} / \mathrm{h}$. Both BK and A779 were infused for the entire duration of experiment until the experiment was finished (end of Ang 1-7 infusion).

Thirty minutes after administration of agonist and antagonist, intravenous infusion of Ang 1-7 at graded doses of 0,100 , and $300 \mathrm{n} \mathrm{kg}^{-1} \mathrm{~min}^{-1}$ was performed using a microsyringe pump (New Era Pump System Inc. Farmingdale, NY, USA). Each dose was given until the response of MAP reached plateau (approx. $15 \mathrm{~min}$ ). Then, the rats were sacrificed humanely and the left kidney was weighed rapidly. The $t$-Student test was applied to analyze the baseline data and ANOVA for repeated measures was used for other data.

\section{Results}

3.1. Baseline Measurement. In baseline measurements, before infusion of BK or BK + A779, the groups were not significantly different in terms of MAP, RPP, RBF, and RBF per gram kidney weight (Figure 1).

3.2. Effect of Agonist and Antagonist. MAP and RPP did not significantly alter when BK or BK + A779 was administered in both OV and OVE groups. The results also indicated that $\mathrm{BK}$ or BK + A779 infusion had no significant effect on RBF percentage change (\%RBF, Figure 2).

3.3. Responses to Ang 1-7 Infusion. A slight increase of MAP response to Ang 1-7 infusion was observed when both A779 and BK were infused. For example, $300 \mathrm{ng} \mathrm{kg}^{-1} \mathrm{~min}^{-1} \mathrm{Ang}$ 1-7 increased MAP from $99.8 \pm 2.4\left(0 \mathrm{ng} \mathrm{kg}^{-1} \mathrm{~min}^{-1}\right)$ to $103.7 \pm$ $2.9 \mathrm{mmHg}$ in OV group and from $99.2 \pm 6\left(0 \mathrm{ng} \mathrm{kg}^{-1} \mathrm{~min}^{-1}\right)$ to $103.8 \pm 5.9 \mathrm{mmHg}$ in OVE group. However, in both the OV and OVE groups, the difference of MAP alteration between the two subgroups induced by Ang 1-7 infusion was not statistically meaningful (Figure 3). As mentioned before, RPP remained constant at the basal value during Ang 
BK
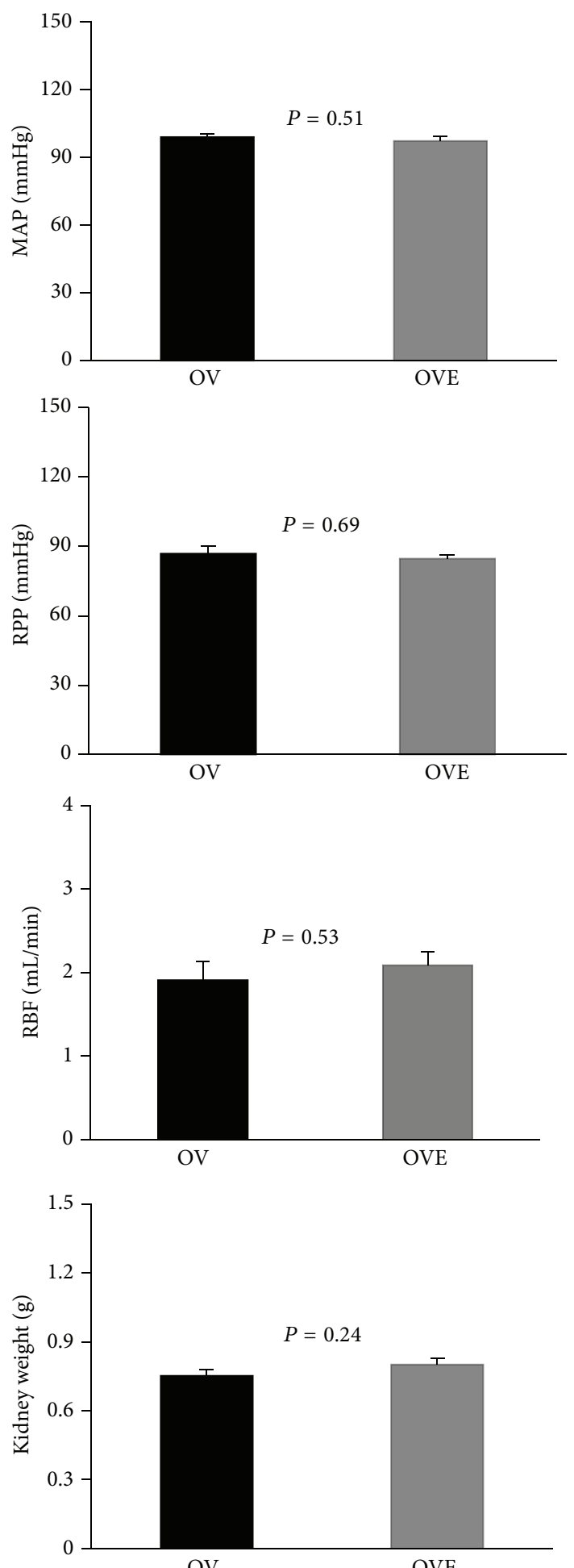

$\mathrm{BK}+\mathrm{A} 779$
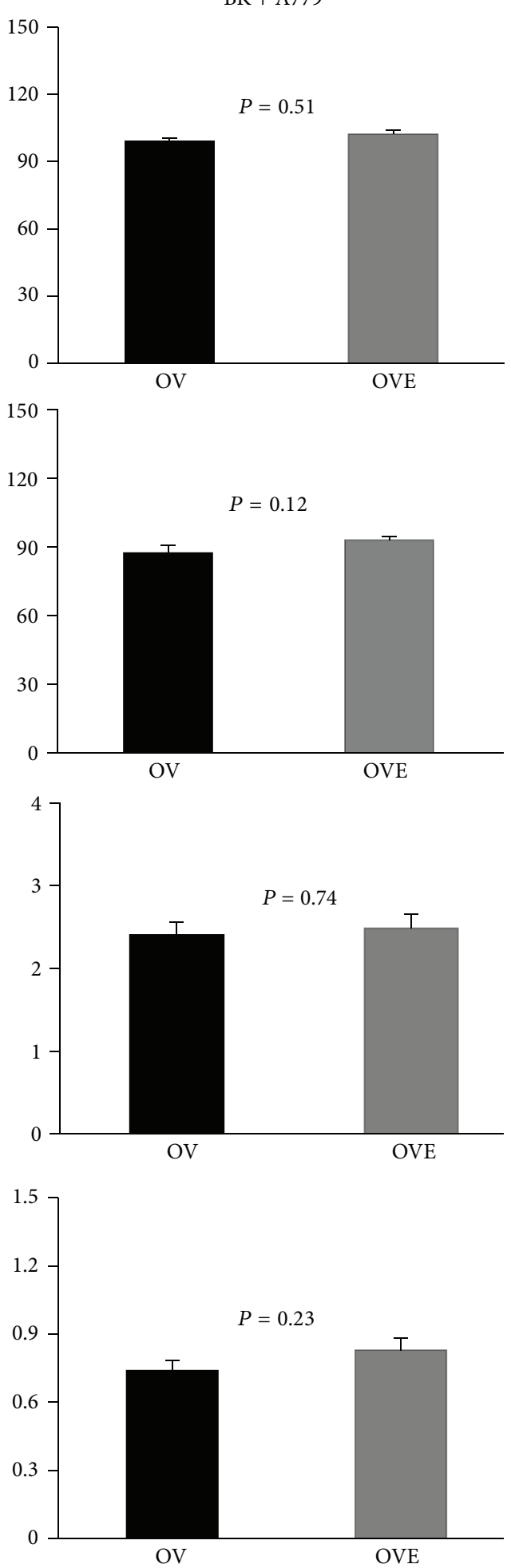

FIGURE 1: Baseline hemodynamic parameters in BK and BK + A779 groups in ovariectomized untreated and ovariectomized estradiol-treated rats. Data are presented as mean \pm SEM. MAP, mean arterial pressure; RPP, renal perfusion pressure; RVR, renal vascular resistance; RBF, renal blood flow per gram kidney weight. There were no significant differences between the groups. 

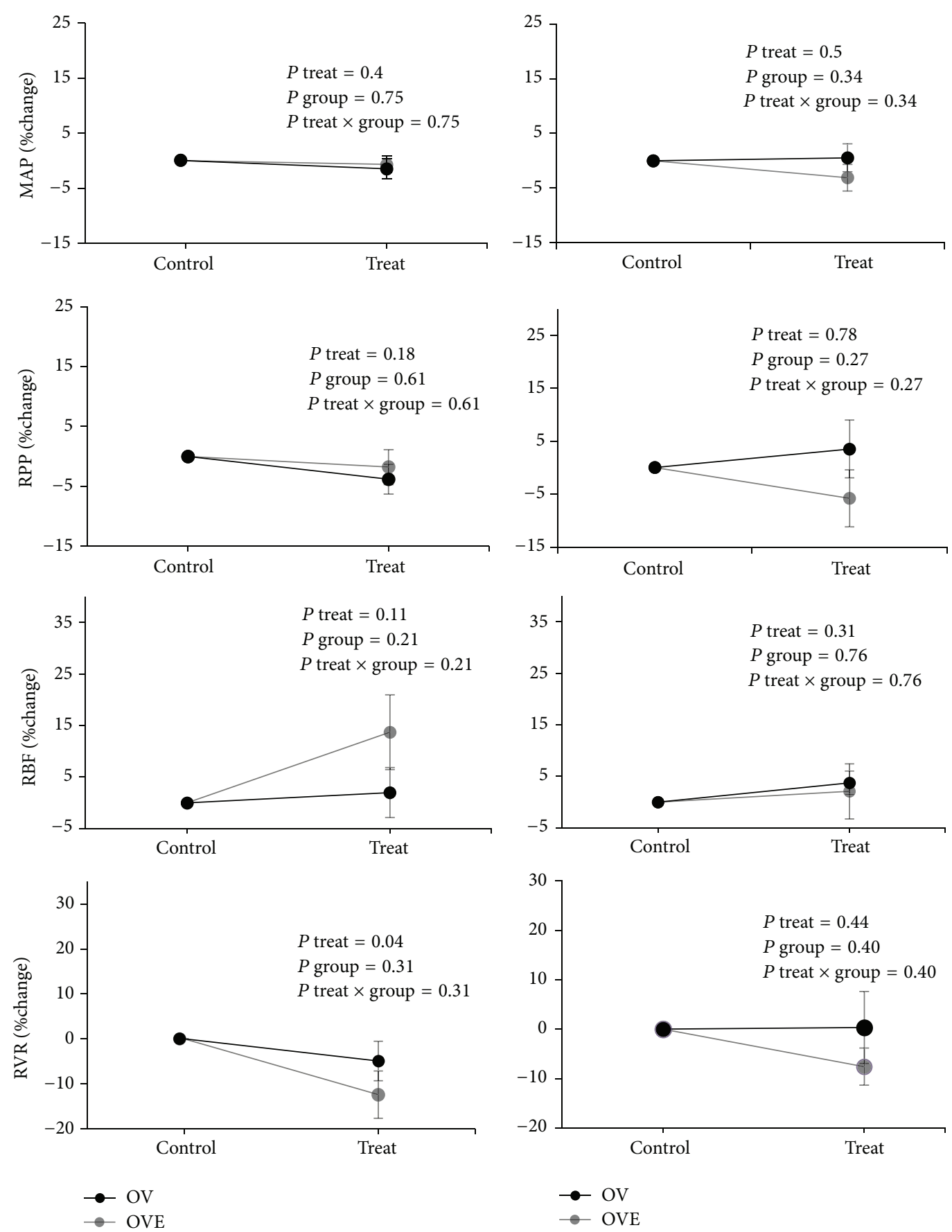

FIGURE 2: Parameters were recorded in ovariectomized and ovariectomized estradiol-treated rats before and after administration of BK or $\mathrm{A} 779+\mathrm{BK}$. Data are presented as mean \pm SEM of percentage changes from the baseline. MAP, mean arterial pressure; RPP, renal perfusion pressure; RVR, renal vascular resistance; RBF, renal blood flow per gram kidney weight. $P$ values were derived from repeated measures ANOVA.

1-7 infusion. Ang 1-7 infusion increased \%RBF in a dosedependent manner in all the groups $(P$ dose $<0.001)$. BK alone administration increased \%RBF response to Ang 1-7 in the OVE group compared with the OV group $(P<0.05)$.
For example, $300 \mathrm{ng} \mathrm{kg}^{-1} \mathrm{~min}^{-1}$ Ang 1-7 increased RBF by $6.9 \pm 1.9 \%$ in OVE group versus $0.9 \pm 1.8 \%$ in OV group. Interestingly, when BK plus A779 was infused, RBF response was enhanced dose-dependently in both groups with greater 
BK
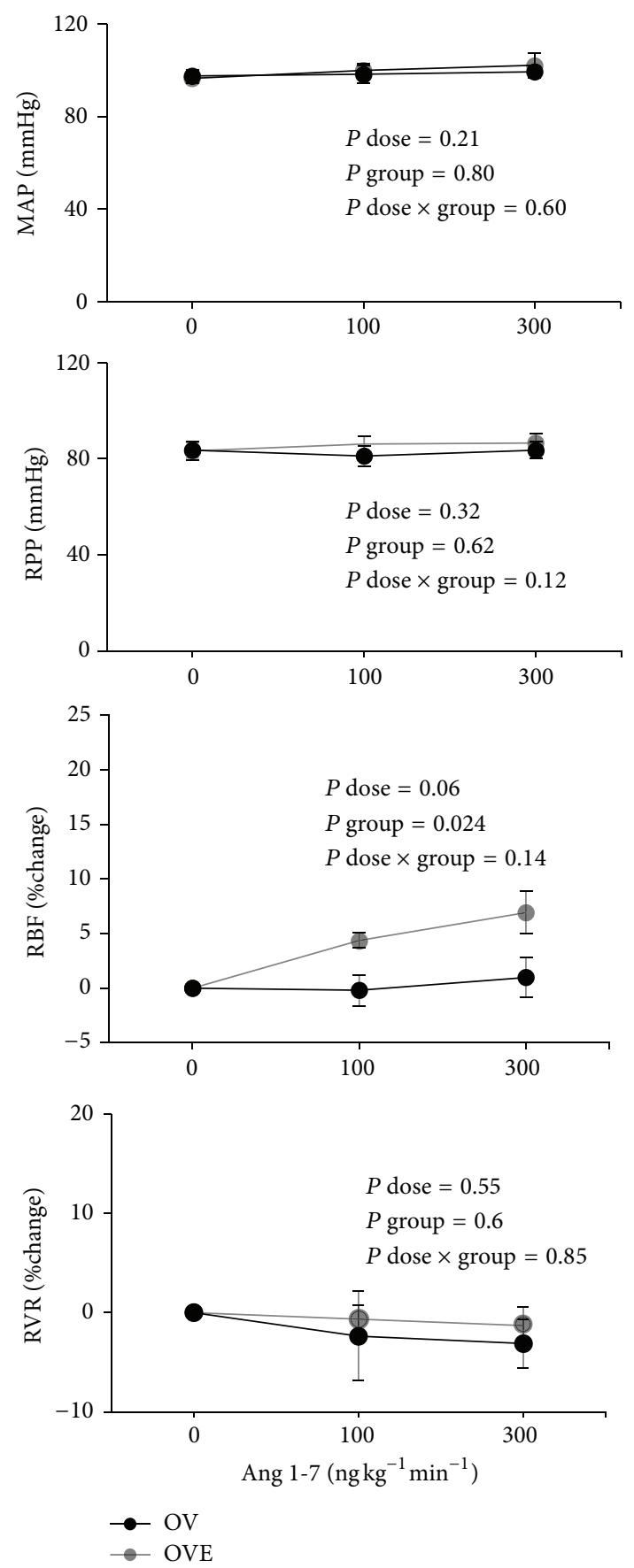

$\mathrm{BK}+\mathrm{A} 779$
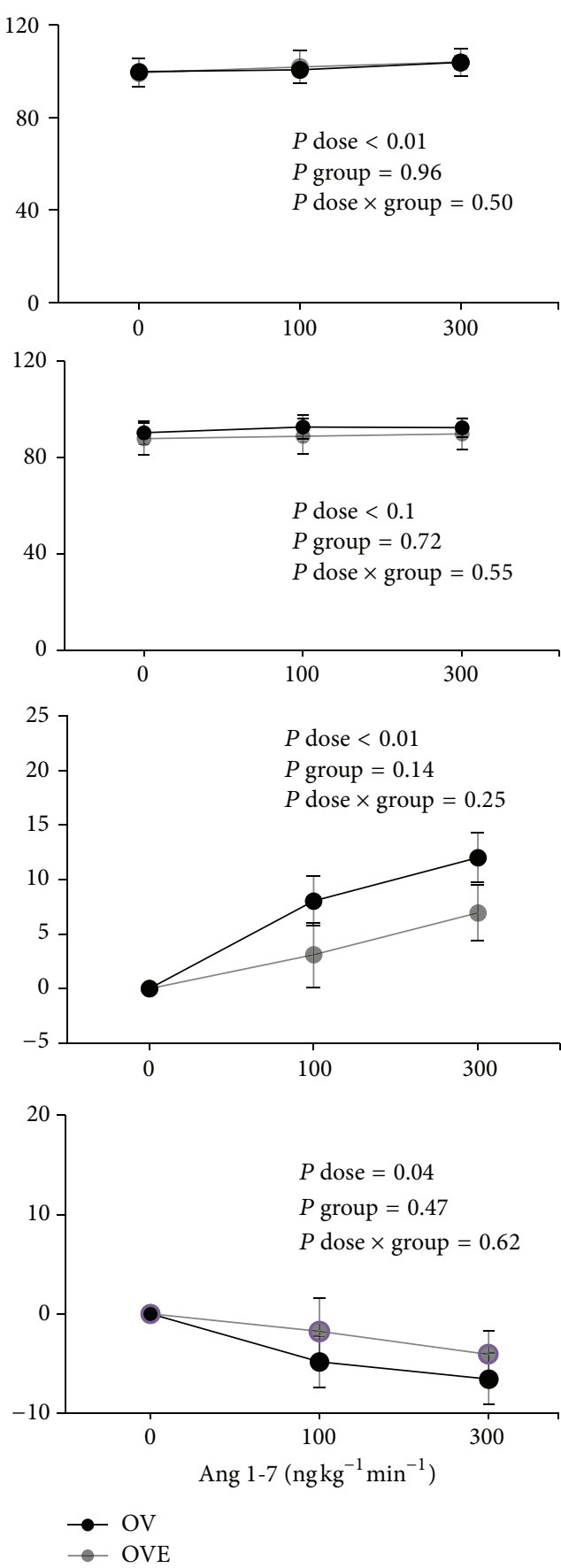

FIGURE 3: RBF, MAP, RPP, and RVR responses to Ang 1-7 were present when BK or A779 + BK was administrated. Data are shown as mean \pm SEM. MAP, mean arterial pressure; RPP, renal perfusion pressure; RVR, renal vascular resistance; RBF, renal blood flow. $P$ values were derived from repeated measures ANOVA.

response in the OV group. For example, $300 \mathrm{ng} \mathrm{kg}^{-1} \mathrm{~min}^{-1}$ Ang $1-7$ increased $\mathrm{RBF}$ by $12 \pm 2.2 \%$ in $\mathrm{OV}$ group versus $7 \pm 2.5 \%$ in OVE group.

\section{Discussion}

The present study was performed to determine the effect of MasR antagonist, A779, on the RBF response to Ang 1-7 in the presence of $\mathrm{BK}$ in ovariectomized rats that were treated with vehicle or estradiol. Our major finding is that administration of BK promotes RBF response to Ang 1-7 in estradiol-treated rats when MasR is not blocked. However, surprisingly, when A779 was added, RBF response to Ang 1-7 increased in a dosedependent manner in both the OV and OVE groups, while $\mathrm{RBF}$ response in the OV group was insignificantly greater than that in the OVE group. 
Some observations show that estrogen contributes to modulate components of renal KKS and RAS, and it regulates renal hemodynamics via these two systems [6-8, 39]. B2 receptor mRNA levels were reduced by ovariectomy in the aorta and kidney, and this alteration is reformed by estrogen replacement [7]. Animal study also supports that renal kallikrein and kallikrein mRNA levels of rats are enhanced in females compared with males; and these factors were decreased by ovariectomy and estrogen treatment returns them back to normal levels [39]. Additionally, hormone replacement therapy (HRT) in postmenopausal women increases plasma concentration of BK and decreases ACE activity [40]. Estradiol enhances expression of renal ACE2 and consequently increases Ang 1-7 level [6]. Previous study showed that, in the heart of ovariectomized rats, estrogen depletion does not alter MasR expression, but estradiol therapy reduces its expression [41]. Estrogen replacement also enhances the relaxation response of Ang 1-7 in female ovariectomized rats, and this alternation is blocked by Ang 1-7 receptor antagonist, D-[ $\left.\mathrm{Ala}^{7}\right]$-Ang 1-7 [42]. In the uterine arteries of sheep, estrogen stimulates the vasodilator response to BK by enhancement of NO release and NO synthase (NOS) activity [43]. Therefore, renoprotective role of estrogen may result from enhanced plasma levels of NO, BK, and Ang 1-7 and reduction in the arterial blood pressure and ACE activity. Our results are in accordance with the findings of the studies that declare that in the presence of BK estradiol enhances the RBF response to Ang 1-7.

The kidney effects of Ang 1-7 and BK are a complex pathway. Ang 1-7 regulates renal hemodynamics, glomerular filtration rate, and tubular transport [44-47]. It also modifies RBF through release of prostanoids and NO [47-50], where Ang 1-7 via MasR regulates renal function [51] in a gender dependent manner [34]. It is reported that Ang 17 increases blood flow in the kidney, brain, and mesentery [48]. Nematbakhsh and Safari suggested that RBF response to Ang 1-7 is different between males and females [34] possibly due to higher MasR expression in females [52]. This is while $\mathrm{BK}$ exerts variable effects on the renal vascular bed. Ren et al. demonstrated that BK has a vasodilator effect on efferent arterioles [53], and its effect on vascular tone is modulated by releasing vasodilator mediators such as $\mathrm{NO}$ and prostaglandins $[24,54,55]$. It seems that renal B2 receptor causes vasodilation. Hock et al. confirmed that the selective B2 receptor antagonist, icatibant, inhibits relaxation response to $\mathrm{BK}$ in renal vascular preparation [56]. In another study, it was demonstrated that des-Arg9-BK, a selective B1 receptor agonist, was involved in vasoconstriction in the kidney and this response is abolished by $\mathrm{B} 1$ receptor antagonist [57]. In fact, the main renal vascular response to $\mathrm{BK}$ in the isolated perfused kidney was vasodilation [58]. The dose of BK is also another factor contributing to different actions of BK on renal circulation. BK in high doses produces vasoconstriction in renal vessels, while at low doses it causes vasodilation [59]. Hoagland et al. observed that intravenous administration of $\mathrm{BK}$ induces significant increase in RBF and decrease in RVR [33]. In addition, BK increases medullary RBF but does not alter cortical RBF [55]. Our data supports that BK enhances $\mathrm{RBF}$ in response to Ang 1-7 in a dose-dependent manner.
It is reported that, in $\mathrm{B} 2$ receptor knockout mice, $\mathrm{RBF}$ and blood pressure do not alter compared with the control mice. However, when the two groups were subjected to high salt diet, RBF decreased in B2 receptor knockout mice [60]. Therefore, the regulatory action of endogenous BK on renal function and blood pressure is dependent on physiological and pharmacological conditions [60].

Another point is the MasR effects. An in vivo experiment showed that Ang 1-7 induces vasodilation of mesenteric vessels by facilitation of BK, while losartan, as an AT1R blocker, does not affect this mechanism. However, A779 blocks this vasodilation, suggesting that BK-potentiating activity of Ang 1-7 is not dependent on its interaction with AT1R while MasR is involved [29]. MasR deficient vessels show vascular endothelium dysfunction. Peiró et al. evaluated response to Ang 1-7 in Mas deficient vessels compared with wild type mice treated with A799 [61]. According to the results, Ang 17 mediated relaxation was reduced by $40 \%$ in isolated vessels of knockout MasR; and A799 diminished dilation response to Ang 1-7 [61]. Additionally, residual vascular relaxation was demonstrated in response to Ang 1-7; therefore, this peptide may act via another pathway [62]. In another study, mesenteric vessels were isolated and A779 and NO synthase (NOS) inhibitor, L-NAME, were administrated and it was shown that the vasorelaxant responses of Ang 1-7 and BK were abolished by A779 and L-NAME [63]. It is concluded that MasR has a central role in endothelial NO-mediated relaxation by Ang 1-7 and BK [63]. In the current study, not only did blockade of MasR significantly enhance RBF response to Ang 1-7, but also this $\mathrm{RBF}$ alternation is higher in the vehicle group than in the estradiol-treated animals. Consequently, when MasR is blocked, RBF response to Ang 1-7 may be related to another pathway. We cannot provide the exact mechanism for such observation, but one explanation is that BK potentiates vasodilatory effect of Ang 1-7 by its receptor and also other angiotensin receptors such as AT2R may be involved [64]. To summarize, RBF response to Ang 1-7 seems to be related to several factors including RAS receptors, $\mathrm{BK}, \mathrm{NO}$, and prostaglandins. All those factors integrate to control renal hemodynamics. In the absence of one factor, others help compensate and make a greater response.

\section{Conclusion}

Some data support the exclusive MasR mediated vasodilator response of Ang 1-7 [29, 63], while others confirm that other receptors are involved and MasR has a partial role $[61,62]$. Furthermore, cooperation between BK and Ang 1-7 appears to have a critical role in the vasodilatory effect that is mediated by BK receptor. Considering the role of estrogen on RAS and KKS, we concluded that BK and estradiol increased $\mathrm{RBF}$ response to Ang 1-7 infusion and this action may not be related to MasR.

\section{Conflict of Interests}

The authors declare that there is no conflict of interests regarding the publication of this paper. 


\section{Acknowledgment}

This study was supported by Isfahan University of Medical Sciences.

\section{References}

[1] L. Gouva and A. Tsatsoulis, "The role of estrogens in cardiovascular disease in the aftermath of clinical trials," Hormones, vol. 3, no. 3, pp. 171-183, 2004.

[2] M. C. Chappell, A. C. Marshall, E. M. Alzayadneh, H. A. Shaltout, and D. I. Diz, "Update on the angiotensin converting enzyme 2-angiotensin (1-7)-Mas receptor axis: fetal programing, sex differences, and intracellular pathways," Frontiers in Endocrinology, vol. 4, article 201, 2013.

[3] S. L. Seliger, C. Davis, and C. Stehman-Breen, "Gender and the progression of renal disease," Current Opinion in Nephrology and Hypertension, vol. 10, no. 2, pp. 219-225, 2001.

[4] A. K. Sampson, K. M. Moritz, E. S. Jones, R. L. Flower, R. E. Widdop, and K. M. Denton, "Enhanced angiotensin II type 2 receptor mechanisms mediate decreases in arterial pressure attributable to chronic low-dose angiotensin II in female rats," Hypertension, vol. 52, no. 4, pp. 666-671, 2008.

[5] I. Armando, M. Jezova, A. V. Juorio et al., "Estrogen upregulates renal angiotensin II AT2 receptors," The American Journal of Physiology-Renal Physiology, vol. 283, no. 5, pp. F934-F943, 2002.

[6] H. Ji, S. Menini, W. Zheng, C. Pesce, X. Wu, and K. Sandberg, "Role of angiotensin-converting enzyme 2 and angiotensin(17 ) in $17 \beta$-oestradiol regulation of renal pathology in renal wrap hypertension in rats," Experimental Physiology, vol. 93, no. 5, pp. 648-657, 2008.

[7] P. Madeddu, C. Emanueli, M. V. Varoni et al., "Regulation of bradykinin $\mathrm{B}_{2}$-receptor expression by oestrogen," British Journal of Pharmacology, vol. 121, no. 8, pp. 1763-1769, 1997.

[8] H. Sumino, S. Ichikawa, T. Kanda et al., "Hormone replacement therapy in postmenopausal women with essential hypertension increases circulating plasma levels of bradykinin," American Journal of Hypertension, vol. 12, no. 10, pp. 1044-1047, 1999.

[9] C. M. Ferrario and S. N. Iyer, "Angiotensin-(1-7): a bioactive fragment of the renin-angiotensin system," Regulatory Peptides, vol. 78, no. 1-3, pp. 13-18, 1998.

[10] J. Joyner, L. A. A. Neves, J. P. Granger et al., “Temporal-spatial expression of ANG-(1-7) and angiotensin-converting enzyme 2 in the kidney of normal and hypertensive pregnant rats," The American Journal of Physiology-Regulatory Integrative and Comparative Physiology, vol. 293, no. 1, pp. R169-R177, 2007.

[11] R. A. S. Santos, A. C. Simoes e Silva, C. Maric et al., "Angiotensin-(1-7) is an endogenous ligand for the G protein-coupled receptor Mas," Proceedings of the National Academy of Sciences of the United States of America, vol. 100, no. 14, pp. 8258-8263, 2003.

[12] Z. Zhu, J. Zhong, S. Zhu, D. Liu, M. van der Giet, and M. Tepel, "Angiotensin-(1-7) inhibits angiotensin II-induced signal transduction," Journal of Cardiovascular Pharmacology, vol. 40, no. 5, pp. 693-700, 2002.

[13] M. Iwai and M. Horiuchi, "Devil and angel in the reninangiotensin system: ACE-angiotensin II-AT1 receptor axis vs. ACE2-angiotensin-(1-7)-Mas receptor axis," Hypertension Research, vol. 32, no. 7, pp. 533-536, 2009.
[14] R. A. S. Santos, A. J. Ferreira, and A. C. S. e Silva, "Recent advances in the angiotensin-converting enzyme 2-angiotensin(1-7)-Mas axis," Experimental Physiology, vol. 93, no. 5, pp. 519-527, 2008.

[15] M. Luque, P. Martin, N. Martell, C. Fernandez, K. B. Brosnihan, and C. M. Ferrario, "Effects of captopril related to increased levels of prostacyclin and angiotensin-(1-7) in essential hypertension," Journal of Hypertension, vol. 14, no. 6, pp. 799-805, 1996.

[16] C. M. Ferrario, J. Jessup, P. E. Gallagher et al., "Effects of renin-angiotensin system blockade on renal angiotensin-(1-7) forming enzymes and receptors," Kidney International, vol. 68, no. 5, pp. 2189-2196, 2005.

[17] M. Donoghue, F. Hsieh, E. Baronas et al., "A novel angiotensinconverting enzyme-related carboxypeptidase (ACE2) converts angiotensin I to angiotensin 1-9," Circulation Research, vol. 87, no. 5, pp. el-e9, 2000.

[18] M. C. Chappell, A. J. Allred, and C. M. Ferrario, "Pathways of angiotensin-(1-7) metabolism in the kidney," Nephrology Dialysis Transplantation, vol. 16, supplement 1, pp. 22-26, 2001.

[19] M. C. Chappell, N. T. Pirro, A. Sykes, and C. M. Ferrario, "Metabolism of angiotensin-(1-7) by angiotensin-converting enzyme," Hypertension, vol. 31, no. 1, pp. 362-367, 1998.

[20] H. S. Margolius, "Kallikreins and kinins: molecular characteristics and cellular and tissue responses," Diabetes, vol. 45, supplement 1, pp. S14-S19, 1996.

[21] K. D. Bhoola, C. D. Figueroa, and K. Worthy, "Bioregulation of kinins: kallikreins, kininogens, and kininases," Pharmacological Reviews, vol. 44, no. 1, pp. 1-80, 1992.

[22] D. J. Campbell, "Towards understanding the kallikrein-kinin system: insights from measurement of kinin peptides," Brazilian Journal of Medical and Biological Research, vol. 33, no. 6, pp. 665-677, 2000.

[23] R. L. Hébert, D. Regoli, H. Xiong, M. D. Breyer, and G. E. Plante, "Bradykinin B2 type receptor activation regulates fluid and electrolyte transport in the rabbit kidney," Peptides, vol. 26, no. 8, pp. 1308-1316, 2005.

[24] N.-E. Rhaleb, X.-P. Yang, and O. A. Carretero, “The Kallikreinkinin system as a regulator of cardiovascular and renal function," Comprehensive Physiology, vol. 1, no. 2, pp. 971-993, 2011.

[25] J.-V. Mombouli and P. M. Vanhoutte, "Heterogeneity of endothelium-dependent vasodilator effects of angiotensinconverting enzyme inhibitors: role of bradykinin generation during ACE inhibition," Journal of Cardiovascular Pharmacology, vol. 20, no. 9, pp. S74-S82, 1992.

[26] E. G. Erdös, F. Tan, and R. A. Skidgel, "Angiotensin I-converting enzyme inhibitors are allosteric enhancers of kinin B1 and B2 receptor function," Hypertension, vol. 55, no. 2, pp. 214-220, 2010.

[27] K. B. Brosnihan, P. Li, and C. M. Ferrario, "Angiotensin-(17) dilates canine coronary arteries through kinins and nitric oxide," Hypertension, vol. 27, no. 3, pp. 523-528, 1996.

[28] A. Abbas, G. Gorelik, L. A. Carbini, and A. G. Scicli, "Angiotensin-(1-7) induces bradykinin-mediated hypotensive responses in anesthetized rats," Hypertension, vol. 30, no. 2, pp. 217-221, 1997.

[29] M. A. Oliveira, Z. B. Fortes, R. A. S. Santos, M. C. Kosla, and M. H. C. De Carvalho, "Synergistic effect of angiotensin-(1-7) on bradykinin arteriolar dilation in vivo," Peptides, vol. 20, no. 10, pp. 1195-1201, 1999. 
[30] R. W. Schrier and W. Wang, "Acute renal failure and sepsis," The New England Journal of Medicine, vol. 351, no. 2, pp. 159-169, 2004.

[31] C. J. Lote, L. Harper, and C. O. S. Savage, "Mechanisms of acute renal failure," British Journal of Anaesthesia, vol. 77, no. 1, pp. 82-89, 1996.

[32] V. E. Torres, B. F. King, A. B. Chapman et al., "Magnetic resonance measurements of renal blood flow and disease progression in autosomal dominant polycystic kidney disease," Clinical Journal of the American Society of Nephrology, vol. 2, no. 1, pp. 112-120, 2007.

[33] K. M. Hoagland, D. A. Maddox, and D. S. Martin, "Bradykinin B2-receptors mediate the pressor and renal hemodynamic effects of intravenous bradykinin in conscious rats," Journal of the Autonomic Nervous System, vol. 75, no. 1, pp. 7-15, 1999.

[34] M. Nematbakhsh and T. Safari, "Role of Mas receptor in renal blood flow response to angiotensin (1-7) in male and female rats," General Physiology and Biophysics, vol. 33, no. 3, pp. 365372, 2014.

[35] K. D. da Silveira, K. S. P. Bosco, L. R. L. Diniz et al., "ACE2angiotensin-(1-7)-Mas axis in renal ischaemia/reperfusion injury in rats," Clinical Science, vol. 119, no. 9, pp. 385-394, 2010.

[36] S. Bachmann and P. Mundel, "Nitric oxide in the kidney: synthesis, localization, and function," American Journal of Kidney Diseases, vol. 24, no. 1, pp. 112-129, 1994.

[37] Z. Pezeshki, M. Nematbakhsh, S. Mazaheri et al., "Estrogen abolishes protective effect of erythropoietin against cisplatininduced nephrotoxicity in ovariectomized rats," ISRN Oncology, vol. 2012, Article ID 890310, 7 pages, 2012.

[38] S. Bosnyak, E. S. Jones, A. Christopoulos, M.-I. Aguilar, W. G. Thomas, and R. E. Widdop, "Relative affinity of angiotensin peptides and novel ligands at AT1 and AT2 receptors," Clinical Science, vol. 121, no. 7, pp. 297-303, 2011.

[39] P. Madeddu, N. Glorioso, M. Maioli et al., "Regulation of rat renal kallikrein expression by estrogen and progesterone," Journal of Hypertension, vol. 9, no. 6, pp. S244-S245, 1991.

[40] A. J. Proudler, D. Crook, J. C. Stevenson, A. I. H. Ahmed, J. M. Rymer, and I. Fogelman, "Hormone replacement therapy and serum angiotensin-converting-enzyme activity in postmenopausal women," The Lancet, vol. 346, no. 8967, pp. 89-90, 1995.

[41] H. Wang, J. A. Jessup, Z. Zhao et al., "Characterization of the cardiac renin angiotensin system in oophorectomized and estrogen-replete mRen2. Lewis rats," PLoS ONE, vol. 8, no. 10, Article ID e76992, 2013.

[42] L. A. A. Neves, D. B. Averill, C. M. Ferrario, J. L. Aschner, and K. B. Brosnihan, "Vascular responses to angiotensin-(-7) during the estrous cycle," Endocrine, vol. 24, no. 2, pp. 161-165, 2004.

[43] J.-C. Veille, P. Li, J. C. Eisenach, A. G. Massmann, and J. P. Figueroa, "Effects of estrogen on nitric oxide biosynthesis and vasorelaxant activity in sheep uterine and renal arteries in vitro," American Journal of Obstetrics and Gynecology, vol. 174, no. 3, pp. 1043-1049, 1996.

[44] E. A. van der Wouden, P. Ochodnický, R. P. E. van Dokkum et al., "The role of angiotensin(1-7) in renal vasculature of the rat," Journal of Hypertension, vol. 24, no. 10, pp. 1971-1978, 2006.

[45] V. Vallon, N. Heyne, K. Richter, M. C. Khosla, and K. Fechter, "[7-D-ALA]-angiotensin 1-7 blocks renal actions of angiotensin 1-7 in the anesthetized rat," Journal of Cardiovascular Pharmacology, vol. 32, no. 1, pp. 164-167, 1998.
[46] R. K. Handa, C. M. Ferrario, and J. W. Strandhoy, "Renal actions of angiotensin-(1-7): in vivo and in vitro studies," American Journal of Physiology, vol. 270, no. 1, pp. F141-F147, 1996.

[47] Y. Ren, J. L. Garvin, and O. A. Carretero, "Vasodilator action of angiotensin-(1-7) on isolated rabbit afferent arterioles," Hypertension, vol. 39, no. 3, pp. 799-802, 2002.

[48] W. O. Sampaio, A. A. S. Nascimento, and R. A. S. Santos, "Systemic and regional hemodynamic effects of angiotensin(1-7) in rats," The American Journal of Physiology-Heart and Circulatory Physiology, vol. 284, no. 6, pp. H1985-H1994, 2003.

[49] G. A. Botelho-Santos, W. O. Sampaio, T. L. Reudelhuber, M. Bader, M. J. Campagnole-Santos, and R. A. S. Dos Santos, "Expression of an angiotensin-(1-7)-producing fusion protein in rats induced marked changes in regional vascular resistance," The American Journal of Physiology-Heart and Circulatory Physiology, vol. 292, no. 5, pp. H2485-H2490, 2007.

[50] I. F. Benter, D. I. Diz, and C. M. Ferrario, "Cardiovascular actions of angiotensin (1-7)," Peptides, vol. 14, no. 4, pp. 679684, 1993.

[51] S. V. B. Pinheiro, A. J. Ferreira, G. T. Kitten et al., "Genetic deletion of the angiotensin-(1-7) receptor Mas leads to glomerular hyperfiltration and microalbuminuria," Kidney International, vol. 75, no. 11, pp. 1184-1193, 2009.

[52] A. K. Sampson, K. M. Moritz, and K. M. Denton, "Postnatal ontogeny of angiotensin receptors and ACE2 in male and female rats," Gender Medicine, vol. 9, no. 1, pp. 21-32, 2012.

[53] Y. Ren, J. Garvin, and O. A. Carretero, "Mechanism involved in bradykinin-induced efferent arteriole dilation," Kidney International, vol. 62, no. 2, pp. 544-549, 2002.

[54] L. G. Navar, E. W. Inscho, D. S. A. Majid, J. D. Imig, L. M. Harrison-Bernard, and K. D. Mitchell, "Paracrine regulation of the renal microcirculation," Physiological Reviews, vol. 76, no. 2, pp. 425-536, 1996.

[55] B. Badzyńska and J. Sadowski, "Differential action of bradykinin on intrarenal regional perfusion in the rat: waning effect in the cortex and major impact in the medulla," The Journal of Physiology, vol. 587, no. 15, pp. 3943-3953, 2009.

[56] F. Hock, K. Wirth, U. Albus et al., "Hoe 140 a new potent and long acting bradykinin-antagonist: in vitro studies," British Journal of Pharmacology, vol. 102, no. 3, pp. 769-773, 1991.

[57] F. Gobeil, W. Neugebauer, C. Filteau et al., "Structure-activity studies of $\mathrm{B}_{1}$ receptor-related peptides. Antagonists," Hypertension, vol. 28, no. 5, pp. 833-839, 1996.

[58] K. Bagaté, L. Develioglu, J.-L. Imbs, B. Michel, J.-J. Helwig, and M. Barthelmebs, "Vascular kinin B1 and B2 receptor-mediated effects in the rat isolated perfused kidney-differential regulations," British Journal of Pharmacology, vol. 128, no. 8, pp. 16431650, 1999.

[59] K. G. Hofbauer, H. Dienemann, P. Forgiarini, R. Stalder, and J. M. Wood, "Renal vascular effects of angiotensin II, arginine-vasopressin and bradykinin in rats: interactions with prostaglandins," General Pharmacology: The Vascular System, vol. 14, no. 1, pp. 145-147, 1983.

[60] A. F. Milia, V. Gross, R. Plehm, J. A. De Silva Jr., M. Bader, and F. C. Luft, "Normal blood pressure and renal function in mice lacking the bradykinin B2 receptor," Hypertension, vol. 37, no. 6, pp. 1473-1479, 2001.

[61] C. Peiró, S. Vallejo, F. Gembardt et al., "Endothelial dysfunction through genetic deletion or inhibition of the G protein-coupled receptor Mas: a new target to improve endothelial function," Journal of Hypertension, vol. 25, no. 12, pp. 2421-2425, 2007. 
[62] D. M. R. Silva, H. R. Vianna, S. F. Cortes, M. J. CampagnoleSantos, R. A. S. Santos, and V. S. Lemos, "Evidence for a new angiotensin-(1-7) receptor subtype in the aorta of SpragueDawley rats," Peptides, vol. 28, no. 3, pp. 702-707, 2007.

[63] C. Peiró, S. Vallejo, F. Gembardt et al., "Complete blockade of the vasorelaxant effects of angiotensin-(1-7) and bradykinin in murine microvessels by antagonists of the receptor Mas," The Journal of Physiology, vol. 591, no. 9, pp. 2275-2285, 2013.

[64] P. E. Walters, T. A. Gaspari, and R. E. Widdop, "Angiotensin(1-7) acts as a vasodepressor agent via angiotensin II type 2 receptors in conscious rats," Hypertension, vol. 45, no. 5, pp. 960-966, 2005. 

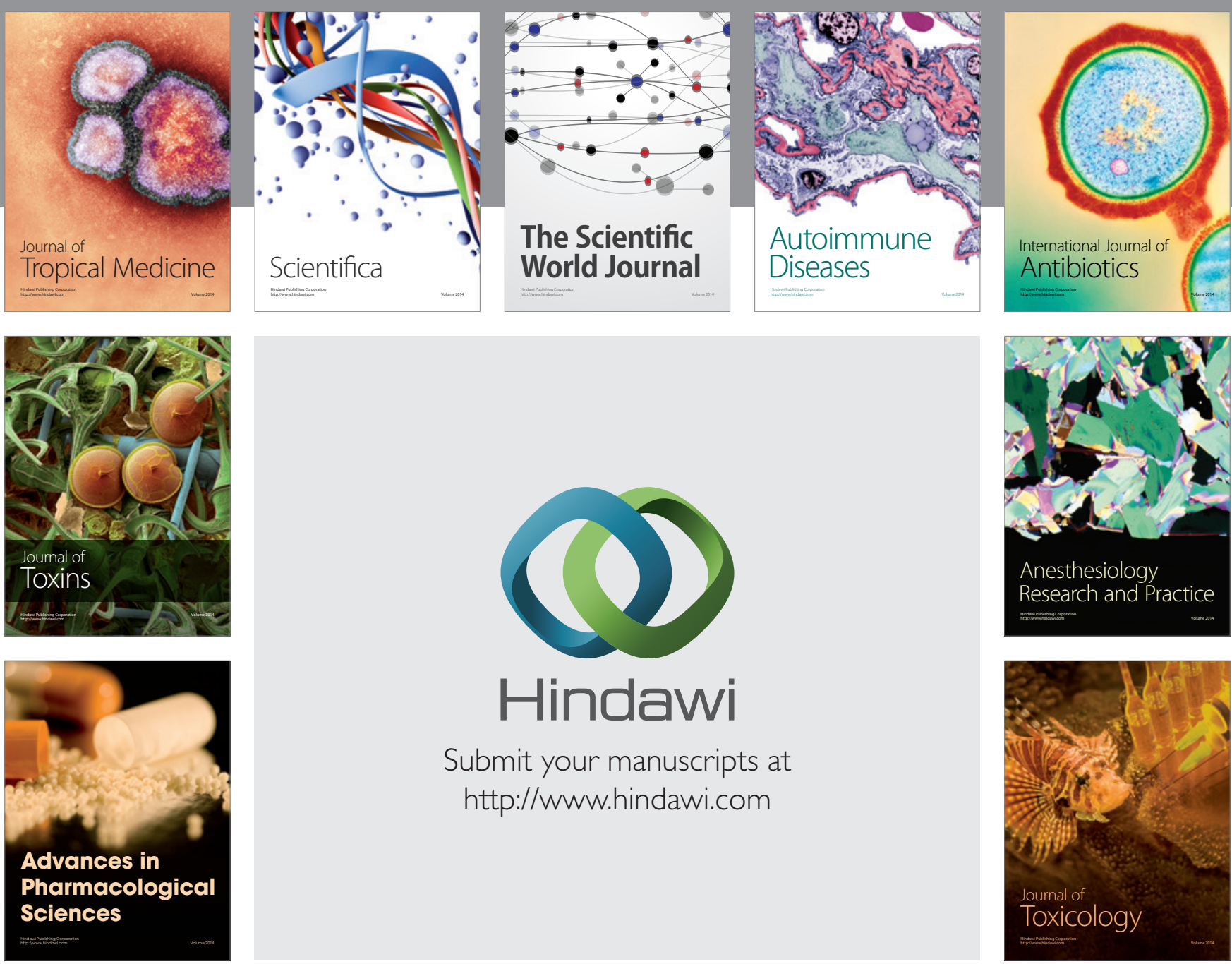

\section{Hindawi}

Submit your manuscripts at

http://www.hindawi.com
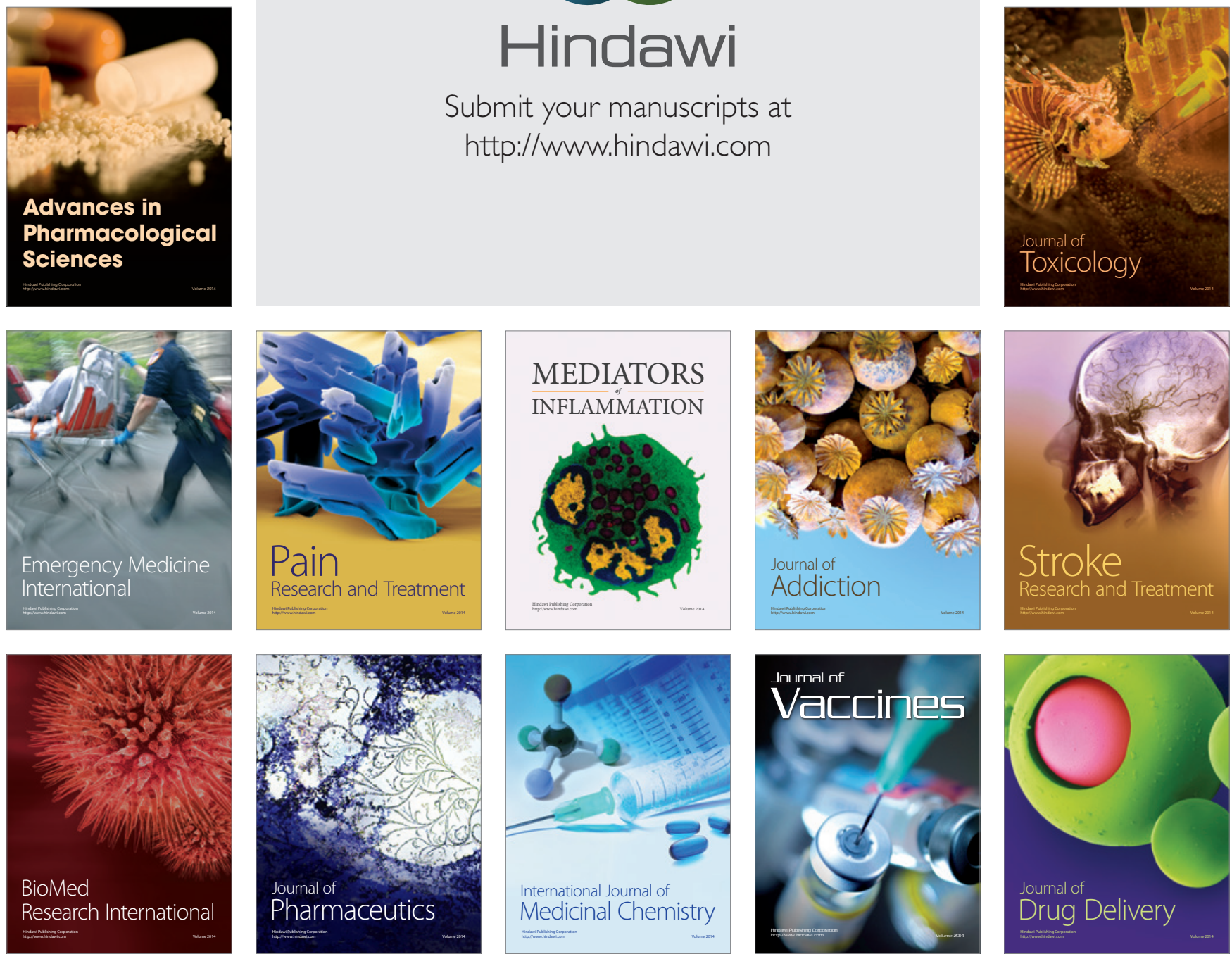